\title{
ÍVHEGESZTŐ ROBOTOK SZENZORJAI
}

\section{ARC WELDING ROBOTS' SENSORS}

\author{
Joao Vitor Martins Rodrigues Pereira ${ }^{1}$, Ricardo Do Amaral Oliveira ${ }^{2}$ \\ Óbudai Egyetem, Bánki Donát Gépész és Biztonságtechnikai Mérnöki Kar, \\ Mechatronikai és Autótechnikai Intézet, Cím: 1038 Magyarország, Budapest, \\ Népszínház utca, 8; Telefon: +36-1-6665400, \\ ${ }^{1}$ joaovitormrodrigues@gmail.com \\ 2 rih.oliveira@hotmail.com
}

\begin{abstract}
This paper presents an introductory content about arc welding robots' sensors, their specific applications to control the robotic welding process and weld seam formation. Application of sensors is required because of geometrical deviations and incorrect positioning of the welded elements to the ideal, or programmed geometries. For this reason sensors are used to reach accurate initial position of welding, further for tracking the welding gap by the welding gun. Quality of welding highly dependent on the arc conditions so the arc control is essential to fulfill this requirement. Beside the arc control the weld pool and seam control are possible aims of sensor applications for arc welding robots. Several kinds of sensors and solutions could be applied starting with the simple touching electrodes through the laser beam based measuring units up to the systems based on image processing. Through some examples, industrial and research phase solutions are described in this paper.
\end{abstract}

Keywords: arc welding robot, sensors, welding gap tracking, weld pool control, weld seam control.

\section{Összefoglalás}

Ebben a cikkben bemutatjuk az ívhegesztő robotoknál alkalmazható legfontosabb szenzorokat, ismertetjük alkalmazásukat a hegesztési folyamat szabályozásában és a hegesztési varrat készítésében. A szenzorok alkalmazása mindenképpen szükséges a hegesztendő darabok geometriai eltérései és helytelen rögzítése miatt, mivel a robotok programjait az ideális geometria alapján készítik el. Éppen ezért szenzorokat kell használni a kezdő hegesztési helyzet megkereséséhez, a hegesztési rés pontos követéséhez. A hegesztés minősége jelentősen függ az ív állapotától, amelynek folyamatos felügyelete is alapvetően fontos. Az ív szabályozása mellett az ömledék és a hegesztett kötés felügyelete is feladata lehet a hegesztő robotoknál alkalmazott szenzoroknak. Sok féle szenzor és műszaki megoldás jöhet szóba, kezdve az egyszerü érintő elektródától, a lézer sugárral mérő egységeken át a képfeldolgozáson alapuló rendszerekig. A cikkben néhány példán keresztül, ipari és kutatási állapotú megoldásokat mutatunk be.

Kulcsszavak: ivhegesztö robot, szenzorok, hegesztési rés követés, hegesztési fürdö szabályozás, hegesztési varrat szabályozás. 


\section{Introduction}

Most of the welding robots applied in automatic welding cells is mainly teach and playback robot. Nevertheless many variables affect welding process, such as the inaccuracy of pre-machining, fixing of workpiece and in-process thermal distortions. These disturbances change the gap size, the seam position and remarkably affect the quality of the welded joints. Robots in teach and playback mode have no adaptive functions and usually weld a weldments with lots of flaws, even burning through or incomplete penetration. So, it is necessary to develop an automatic control system for those welding robots working in teach and playback mode.

\section{Sensors of Cloos robots}

The sensors are used to measure the work piece and supply a position for the robot. There are four mainly CLOOS sensors with different capacity ranges which will be analyzed in this project [1]. They are tactile gas nozzle sensor, arc sensor, laser offline sensor and the laser online sensor. These sensors have different tasks depending on the production requirements.

\subsection{Tactile gas nozzle sensor}

The tactile gas nozzle sensor is a sensor which can determine the work piece position by an electro-mechanical detecting principle. Using an electrical current, the sensor can determine the start and/or end of the weld seam by touching the work piece on three directions. The programmer has to memorize three start points in the system. Using these points, the robot moves on three different directions and determines the weld seam start point (Fig. 1). When the gas nozzle touches the work piece, it discharges an electrical current and the computer can measure the distance, calculating the weld seam start position. It is very useful to ensure a correct weld path even the work piece change the position after the programing.

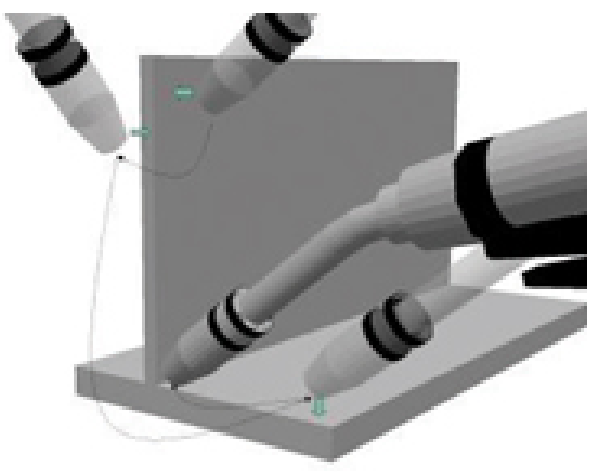

Fig. 1 Finding weld seam start point by gas nozzle

\subsection{Arc sensor}

The arc sensor uses the arc properties to simultaneously weld and measure the joint position of the work piece. It measures whether the torch position is actually following the programmed path during welding. If the measured values, which are obtained electronically from the welding current and voltage, are not the same on both sides, the weld seam position deviates from the programmed path.

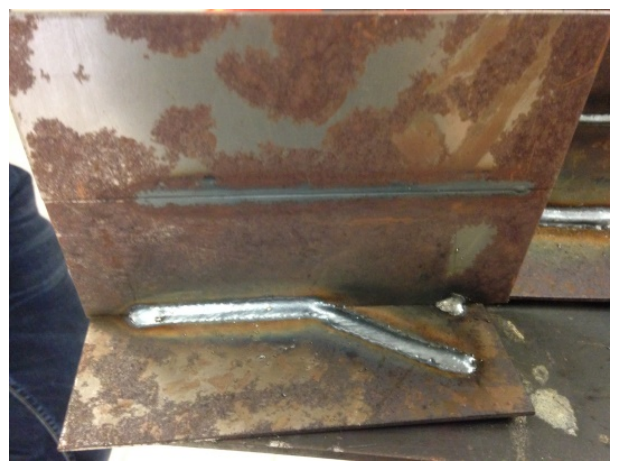

Fig. 2 Misalignment of the weld without arc sensor 
The computer-based robot controller adjusts the welding head position so that the seam is placed exactly in the centre of the joint. In addition, this procedure corrects the distance of the welding torch to the work piece.

\subsection{Offline laser sensor}

Offline laser sensor detects the start and/or the end of the weld seam offline before welding and collects measurement data. It determines the positions and measurements by sending a light beam onto the material surface and receiving the reflection. This sensor can be combined with the arc sensor to improve the quality of the measurements. [2]
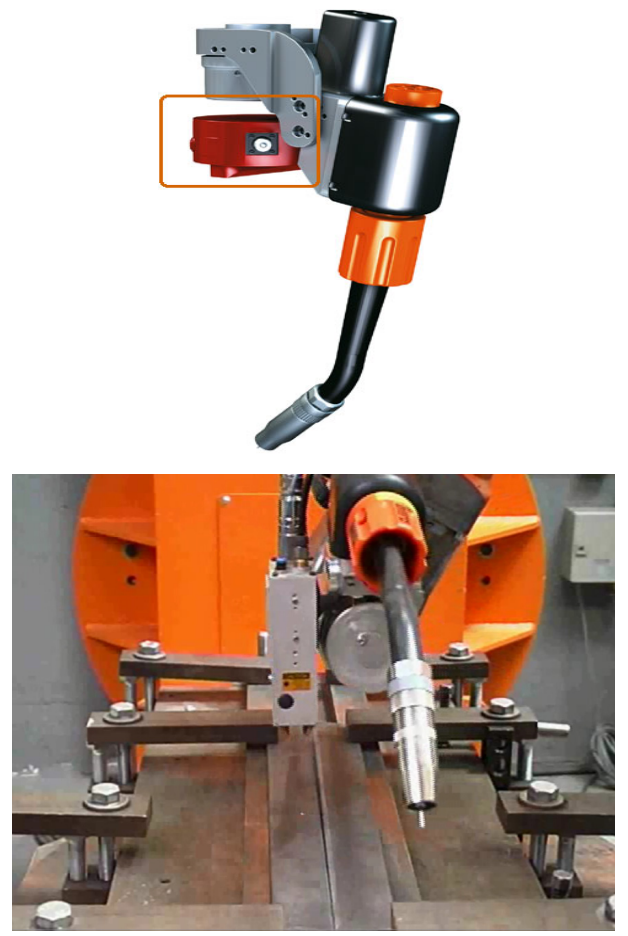

Fig. 3 Searching for the starting point of the weld seam by offline laser sensor

\subsection{Laser online sensor}

The laser online sensor also uses a light beam to measure the section to be welded.
The difference is the laser online sensor work during the welding. Therefore the position of the tooling, the welding torch or the laser beam, and various process parameters are continuously adjusted to improve the quality of the welding.
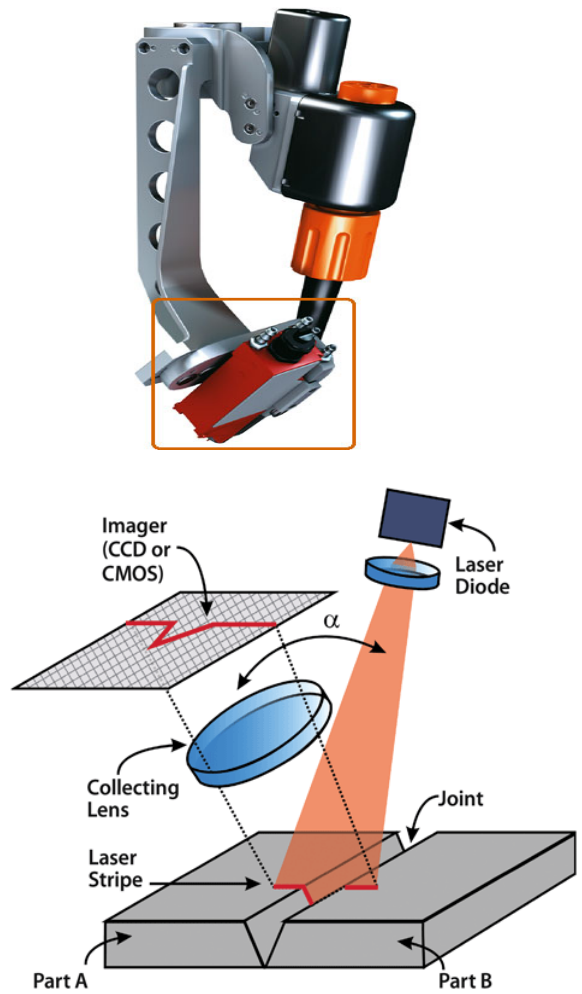

Fig. 4 Operation scheme of an online laser sensor

\section{Researches in robot vision}

There are lots of researches done on the field of robot vision. Most of them are based on image processing solutions for continuous observation and control of the welding process; the weld pool and the resulting weldments.

Passive vision is always a focus in the field of the sensing technique of the welding robot. The passive vision has many advantages, for example, it does not contact 
the weld pool, the information is quite abundant and the cost is low. Most welding related applications are used in seam tracking and weld pool size measuring [3].

The vision-based welding robot system consists of a "teach and playback" robot, a visual sensor, a welding power source, a wire feeder controller, a control computer and an interface box. The visual sensor consists of a charge coupled device (CCD) camera, a wideband filter, two dimmer glasses and reflective mirrors. The light transmission wideband is $590 \mathrm{~nm}$ to 710 $\mathrm{nm}$. The sensor is fixed at the end joint of the robot and moves with the robot. The CCD camera receives the weld pool image through optical filters after twice reflection. The computer captures the images by the image capturing board, extracts the offset and the seam gap using image processing algorithms, and calculates the voltage values for the seam tracking and the welding current and the wire feed rate adjusting. The analogue voltages are sent to the robot controller, the power source and the wire feeder.

The visual sensor captures the images of the weld pool in the top face front. The seam edges and the projection point of the tungsten electrode on the workpiece have been exacted accurately by a series of digital image processing procedures in the image plane coordinate system, such as median filter, edge detection and thinning.

In order to maintain the stability of the welding process, the parameters should be adjusted as little as possible. When the gap is small, a good welding joint can be attained by just adjusting the wire feed rate. But when the gap is too great, the heat input at constant current proves to be larger than that the required and the workpiece would be often burned through.

Wire feed rate is the key factor to compensate for changes in the gap that occur during welding process. In this research, the authors studied the backing weld of aluminium alloy planes with groove, whose reinforcement was required to be in the range of $(-0.5-0) \mathrm{mm}$ with zero gap being most desirable.
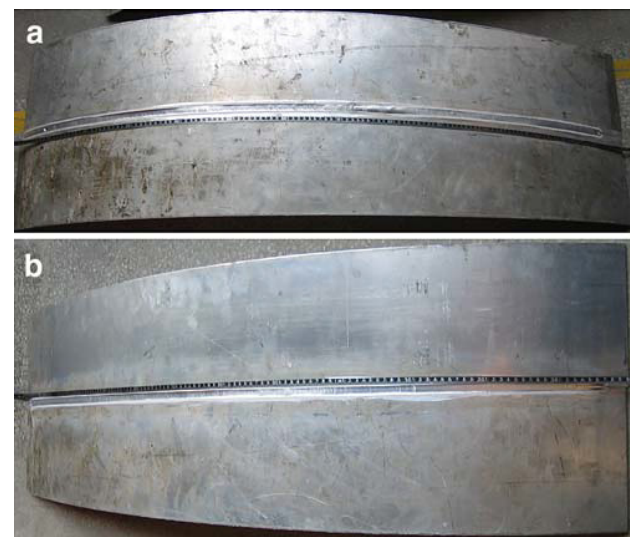

Fig. 5 The result of the product: (a) without control; (b) with automatic control

The passive vision is demonstrated as a feasible method to detect the offset of the torch to the seam and the seam gap during the square-wave AC GTAW.

\section{Conclusions}

Arc welding robot sensors are used to make more reliable the automatic welding process. Applying simple touch probes or developing robot vision based systems several industrial and research solutions are known. Some of these solutions introduced in this paper to show the starting point of further investigations.

\section{References}

[1] www.cloosrobot.com, 19th February 2015.

[2] www.image.thefabricator.com, 19th February 2015.

[3] Hong-yuan Shen, Jing Wu, Tao Lin, Shanben Chen: Arc welding robot system with seam tracking and weld pool control based on passive vision. Springer-Verlag London, International Journal of Advanced Manufacturing Technology (2008) vol. 39. 669-678. 